\title{
Studies on dry matter distribution, harvest index and proximate composition in different accessions of hausa potato (Solenostemon rotundifolius (poir) j. K. Morton) in jos-plateau, Nigeria
}

\begin{abstract}
The Hausa potato (Solenostemon rotundifolius (Poir) J. K. Morton) is a tropical, multipurpose tuberous root crop with different economic uses. Its productivity appears to be limited by a lack of balance between the source potential and sink capacity. This results in generally low yields in cultivated varieties. Consequently, many farmers have abandoned its cultivation, thereby endangering the perpetuity of the crop. This study was, therefore, designed to screen different accessions of the Hausa potato for dry matter production and distribution as well as their proximate composition in the Jos-Plateau environment in north-central Nigeria. Nine accessions (Manchok 1, Manchok 2, Bokkos 1, Bokkos 2, Bikka-Baban, Mujir, NRCRI (White), Tukwak and Langtang) were laid out using the randomized complete block design with five replications. The experiment was conducted between July 2016 and January 2017. Results showed that dry matter accumulation and partitioning varied with accession and time. Total dry matter increased with time up to 126 days after planting in all accessions. The proportion of dry matter was higher in the leaves and stems than in the tubers at the early stages of growth. More dry matter was, however, distributed to the tubers at the latter stages of growth. Generally, harvest index increased with time up to 126 DAP in all but the accession Mujir. Proximate composition varied with accession. The crude fibre, ash and calcium were statistically similar in all accessions. The total tuber yield was generally low in all the accessions, ranging from $0.1 \mathrm{t} \mathrm{ha-1}$ in Mujir and Langtang to $3.83 \mathrm{t} \mathrm{ha}^{-1}$ in NRCRI (White). The study concludes that there is prospect for improving the productivity of the Hausa Potato in the Jos-Plateau environment in order to address food shortages and vitamin $\mathrm{C}$ deficiency among children and pregnant women.
\end{abstract}

Keywords: dry matter, harvest index, proximate composition, hausa potato
Volume 2 Issue 3 - 2018

\author{
Opaleye SA, Namo OAT,Akinbola OJ \\ Department of Plant Science and Technology, University of Jos, \\ Nigeria
}

Correspondence: Namo OAT, Department of Plant Science and Technology, Cytogenetics and plant breeding unit, University of Jos, Nigeria, Email akunamo@yahoo.co.uk

Received: April 07, 2018 | Published: June 22, 2018

\section{Introduction}

The Hausa potato (Solenostemon rotundifolius (Poir) J. K. Morton) is a tropical, multipurpose, minor tuberous root crop. It is one of the best staple tuber crops in terms of its distinctive fragrance, peculiar taste, medicinal, nutritional and economic values. It is cultivated in the West African countries of Ghana and Nigeria. ${ }^{1}$ The plant is a small herbaceous, dicotyledonous annual, $15-30 \mathrm{~cm}$ high, prostate or ascending, with a succulent stem and thick leaves. It has an aromatic mint-like smell. Flowers are small and may be white, blue, pink or pale-violet in colour, and are produced on an elongated terminal with distal inflorescence and slender false spikes. ${ }^{2}$ It has small darkbrown edible tubers produced at the base of the stem. Vegetatively propagated tuber crops like the Hausa potato play a fundamental role in improving food security, human nutrition as well as other uses in the agro-industrial chain. They can be used as substitute for other types of crops in times of economic needs, such as high food prices, bridging the hunger gap between planting and harvesting of the main staple crop or inadequate supply of food in times of famine. ${ }^{3}$ Currently, its genetic resources are disappearing into extinction due to unfavorable features like the small tuber size, ${ }^{1}$ branching of the tubers (which makes them less attractive to consumers), low yield occasioned, perhaps, by lack of balance between its source potential and sink capacity as well as the intense labour required in its production. Consequently, it is being gradually replaced by more popular root and tuber crops like the potato, sweet potato, cassava, cocoyam and yam, which are higher-yielding. The crop is presently classified as an endangered species. The United Nations has predicted that the global human population would rise from 7 billion in 2011 to 9 billion by 2050 , and that the world food production would need to increase between 70 and 100 per cent in forty (40) years. ${ }^{4}$ Most of the increase will need to come from bridging the gap between what is currently achieved per unit land and what should be possible in the future, given the most appropriate farming methods, food storage facilities, availability of suitable cultivars and adaptation to climatic changes. ${ }^{4}$ With the ever-increasing population coupled with limited land, water and other resources, the future beckons on tuber and root crops, including the Hausa potato, in fulfilling the country's food requirements. The Hausa potato has a very high biological efficiency with a profound production potential per unit area of land. ${ }^{5}$ Farmers growing this crop follow indigenous agronomic practices which, coupled with lack of high-yielding varieties, result in generally low yields. The yield can be increased by adopting improved production 
technologies and cultivars. The crop has the potential and prospects for enlarged adoption into other agro-ecological zones in Nigeria, and thereby contributing to food security, diversification of the local food base and sustaining the livelihood of poor-resource farmers. The need to intensify research efforts in the collection of germplasms, genetic characterization and the analysis of yield potentials and proximate composition of the Hausa potato has become imperative. Therefore, the present work was aimed to study the dry matter distribution, harvest index and proximate composition in some accessions of the Hausa potato in the Jos-Plateau agro-ecological zone in Nigeria.

\section{Materials and methods}

The experiment was conducted between July 2016 and January 2017 at the potato substation of the National Root Crops Research Institute (NRCRI), Kuru-Jos, Nigeria. The site is located at latitude $09^{\circ} 44^{\prime} \mathrm{N}$, longitude $08^{\circ} 47^{\prime} \mathrm{E}$ and at an altitude of $1,293.3 \mathrm{~m}$ above sea level. Nine accessions, which were named after their native areas, were sourced from the germplasm collection of the National Root Crops Research Institute (NRCRI), Kuru and from farmers in Bokkos, Langtang, Bikka-Baban, Tukwak, Mujir and Manchok. These include Manchok 1, Manchok 2, Bokkos 1, Bokkos 2, Bikka-Baban, Mujir, NRCRI (White), Tukwak, and Langtang. Land preparation, including clearing, ploughing, ridging and plot mapping, was done manually on July $4^{\text {th }}$ and $5^{\text {th }}, 2016$. The net plot size was $3 \mathrm{~m} \times 3 \mathrm{~m}\left(9 \mathrm{~m}^{2}\right)$ while the gross plot size was $37 \mathrm{mx} 17 \mathrm{~m}$. The accessions were laid out in a randomized complete block design with five replications. One of the replicates was used for the growth analysis studies. Fresh and healthy tubers were selected and planted at $1 \mathrm{~m}$ between rows and $0.3 \mathrm{~m}$ within rows giving a total of 33, 333 plants per hectare. Planting was done on July 8, 2016. The plots were weeded manually at 21 days after planting and then earthed up to avoid the exposure of the tubers to sunlight. Further weeding was done at 45 and 90 days after planting to control weeds. Fertilizer (NPK 15:15:15) was applied at the rate of $200 \mathrm{~kg} \mathrm{ha}^{-1}$. Field observations and data collection were commenced at 15 days after planting (DAP) and continued until harvest. The total dry matter accumulated and the proportion distributed to the leaves, stems and roots were computed at each harvest at 45.90 and 126 DAP. The harvest index was computed at each harvest at 45, 90 and 126 DAP as follows:

$$
\text { Harvest Index }=\frac{\text { Dry weight of tubers }}{\text { Total dry weight }}
$$

Proximate analysis was carried out to determine the nutritional composition of the nine accessions using the standard methods of the Association of Official Analytical Chemist. ${ }^{6}$ Each accession was analysed in duplicates for dry matter content, crude fibre, crude fat, ash, carbohydrate, calcium, phosphorus, Vitamin $\mathrm{C}$ and iron.

Thermal drying method was used in the determination of moisture content as follows:

$$
\% \text { Moisture content }=100-\% \mathrm{DM}
$$

Crude protein was analysed by determining the total organic nitrogen using the macro-Kjeldhal method: ${ }^{7}$

$$
\% N=\frac{14 x M x V_{1} x V}{\text { Weight of sample }(m g) x V a}
$$

$\%$ Crude protein $=\%$ Nitrogen $x 6.25$
Where,

M: Actual Molarity of acid

V: Titre volume of diluted digest

$\mathrm{V}_{1:}$ Total volume of diluted digest

Va: Aliquote volume distilled

Crude fibre was determined as follows:

$$
\% \text { Crude Fibre }=\frac{C_{1}-C_{2} \times 100}{\text { Weight of original sample }}
$$

\section{$\mathrm{C}_{1}-\mathrm{C}_{2}$ : Loss in weight of original sample on incineration.}

The determination of fat content was done by using the Soxhlet type of direct extraction method according to Herch et al. ${ }^{8}$

$$
\% \text { Fat Content }=\frac{W_{1}-W_{2} \times 100}{\text { Weight of original sample }}
$$

The ash content was determined by using the ignition method according to Nnamani et al. ${ }^{9}$

$$
\% \text { Ash Content }=\frac{\text { Weight of ash } 100}{\text { Weight of sample }}
$$

The carbohydrate in the sample was determined as soluble carbohydrate, also known as nitrogen free extract (NFE). This was computed by subtracting the sum of crude protein, crude fibre, crude fat, ash and moisture content from 100.

Carbohydrate $(\mathrm{NFE})=100-($ protein + fibre + fat + ash + moisture $)$.

Minerals and vitamins which include calcium, phosphorus, Vitamin $\mathrm{C}$ and iron were determined by using the Atomic Absorption Spectrometer. ${ }^{6}$ The nutrient components were correlated with one another by using the multiple correlation analysis. The data collected were subjected to the analysis of variance and the F-test was used to test the significance of treatment effects. Means were separated using the Duncan's new Multiple-Range Test. ${ }^{10}$ The Statistical Package for Social Sciences (SPSS 17.0 Version) was used for the analysis.

\section{Results}

\section{Dry matter accumulation and distribution}

The patterns of dry matter accumulation and distribution to the leaves, stems and tubers in some Hausa potato accessions grown in Kuru in 2016 are shown in Tables 1 \& Tables 2. The total dry matter accumulated increased with time up to 126days after planting (126 DAP) in all the accessions. At the early stages of growth (45 and 90 DAP), more dry matter was partitioned to the leaves and stems than to the tubers. At the latter stages, however, more dry matter was partitioned to the tubers compared to the leaves and stems. In the accession Manchok 1, dry matter accumulated in the leaves and stem increased up to 90 DAP and thereafter decreased. In the tubers, however, dry matters increased up to 126 DAP. At the end of the growing season, $85.5 \%$ of total dry matter accumulated was partitioned to the tubers, leaving only $14.5 \%$ in the leaves and stems (Table 2). In the accession Manchok 2, a similar trend was observed. 
Dry matter accumulated in the leaves and stems decreased with time whereas in the tubers dry matter increased with time up to 126 DAP. More dry matter was distributed to the leaves and stems at the early stages of growth. At the latter stages of growth, more dry matter was distributed to the tubers than the leaves and stems. In the accession Bokkos 1, dry matter accumulated in the leaves and stems increased with time up to 90 DAP and thereafter decreased. The dry matters accumulated in the tubers increased with time up to 126 DAP. The proportion of dry matter distributed to the stems and leaves decreased with time whereas in the tubers dry matter increased with time up to 126 DAP. At the end of the growing season $87.7 \%$ of the total dry matter accumulated has been distributed to the tubers (Table 2). In the accession Bokkos 2, the total dry matter accumulated in the leaves, stems and tubers increased with time up to 126 DAP. The proportion of dry matter in the leaves and stems was higher than in the tubers at the early stages of growth. At the end of the growing season, however, more dry matter $(75.9 \%)$ was distributed to the tubers than the leaves $(12.4 \%)$ and stems $(11.8 \%)$. Dry matter accumulation in the leaves increased up to 90 DAP and thereafter decreased in the accession Bikka-Baban. In the stems and tubers, dry matter accumulation increased up to 126 DAP. The proportion of dry matter in the leaves and stems equaled the proportion in the tubers at the early stages of growth. At the latter stages, however, more dry matter $(83.1 \%)$ was distributed to the tubers than the leaves and stems $(16.9$ $\%$ ) (Table 2).

Table I Dry matter accumulation (g) in some accessions of the Hausa Potato grown in Kuru in 2016

\begin{tabular}{|c|c|c|c|c|c|c|c|c|c|c|c|c|}
\hline \multicolumn{13}{|c|}{ Growth Stage (Days After Planting) } \\
\hline \multirow[t]{2}{*}{ Accession } & \multicolumn{2}{|c|}{ Leaves $(\mathrm{g})$} & \multicolumn{3}{|c|}{ Stems $(g)$} & \multirow[b]{2}{*}{126} & \multicolumn{2}{|c|}{ Tubers (g) } & \multicolumn{4}{|c|}{ Total DM (g) } \\
\hline & 45 & 90 & 126 & 45 & 90 & & 45 & 90 & 126 & 45 & 90 & 126 \\
\hline Manchok I & 1.52 & 5.76 & 2.3 & 2.88 & 4.15 & 3.8 & 3.2 & 5.63 & 35.96 & 7.6 & 15.54 & 42.06 \\
\hline Manchok 2 & 1.26 & 4.89 & 2.81 & 4.98 & 2.4 & 5.52 & 10 & 12.58 & 20.73 & 16.24 & 19.87 & 29.06 \\
\hline Bokkos I & 1.28 & 3.41 & 2.54 & 1.46 & 1.83 & 4.22 & 1.51 & 5.16 & 48.04 & 4.25 & 10.4 & 54.8 \\
\hline Bokkos 2 & 1.61 & 8.12 & 6.35 & 2.53 & 4.47 & 6.04 & 5.94 & 9.68 & 38.98 & 10.08 & 22.27 & 51.37 \\
\hline Bikka-Baban & 2.57 & 7.2 & 3.85 & 3.36 & 5.49 & 8.04 & 5.93 & 6.21 & 58.35 & 11.86 & 18.9 & 70.24 \\
\hline Mujir & 0.49 & 3.87 & 1.77 & 0.65 & 2.53 & 1.81 & 1.51 & 3.64 & 10.04 & 2.65 & 10.04 & 13.62 \\
\hline NRCRI (White) & 2.94 & 9.15 & 2.54 & 4.75 & 3.28 & 5.32 & 8.05 & 15.56 & 33.47 & 15.74 & 27.99 & 41.33 \\
\hline Tukwak & 2.48 & 4.57 & 1.83 & 5.12 & 7.22 & 6.67 & 5.7 & 8.8 & 38.08 & 13.3 & 20.59 & 46.58 \\
\hline Langtang & 1.18 & 6.32 & 3.08 & 1.26 & 6.24 & 3.66 & 3.11 & 4.01 & 11.06 & 5.55 & 16.57 & 17.8 \\
\hline $\mathrm{SE} \pm$ & 0.26 & 0.65 & 0.47 & 0.56 & 0.62 & 0.62 & 0.97 & 1.36 & 5.4 & 1.66 & 1.89 & 6.03 \\
\hline
\end{tabular}

Table 2 Dry matter distribution (\%) in some accessions of the Hausa Potato grown in Kuru in 2016

\begin{tabular}{|c|c|c|c|c|c|c|c|c|c|}
\hline \multicolumn{10}{|c|}{ Growth Stage (Days After Planting) } \\
\hline \multirow{2}{*}{ Accession } & \multicolumn{3}{|c|}{ Leaves } & \multicolumn{3}{|c|}{ Stems } & \multicolumn{3}{|c|}{ Tubers } \\
\hline & 45 & 90 & 126 & 45 & 90 & 126 & 45 & 90 & 126 \\
\hline Manchok I & 20 & 37.07 & 5.47 & 37.89 & 26.71 & 9.03 & 42.11 & 36.23 & 85.5 \\
\hline Manchok 2 & 7.76 & 24.61 & 9.67 & 30.67 & 12.08 & 19 & 61.58 & 63.31 & 71.34 \\
\hline Bokkos I & 30.12 & 32.79 & 4.64 & 34.35 & 17.6 & 7.7 & 35.53 & 49.62 & 87.66 \\
\hline Bokkos 2 & 15.97 & 36.46 & 12.36 & 25.1 & 20.07 & 11.76 & 58.93 & 43.47 & 75.88 \\
\hline Bikka-Baban & 21.67 & 38.1 & 5.48 & 28.33 & 29.05 & 11.45 & 50 & 32.86 & 83.07 \\
\hline Mujir & 18.49 & 38.55 & 13 & 24.53 & 25.2 & 13.29 & 56.98 & 36.25 & 73.72 \\
\hline NRCRI (White) & 18.68 & 32.69 & 6.15 & 30.18 & 11.72 & 12.87 & 51.14 & 55.59 & 80.98 \\
\hline Tukwak & 18.65 & 22.2 & 3.93 & 38.5 & 35.07 & 14.32 & 42.86 & 42.74 & 81.75 \\
\hline Langtang & 21.26 & 38.14 & 17.3 & 22.7 & 37.66 & 20.56 & 56.04 & 24.2 & 62.14 \\
\hline
\end{tabular}


In the accession Mujir, dry matter accumulation in the leaves and stems increased with time up to 90 DAP and thereafter decreased. In the tubers dry matter accumulation increased with time up to 126 DAP. The proportion of the dry matter partitioned to the leaves and stems was higher at the early stages of growth than at the latter stages. At the end of the growing season, $73.7 \%$ of the total dry matter produced was partitioned to the tubers, while only $26.3 \%$ was partitioned to the leaves and stems (Table 2). In the accession NRCRI (White), dry matter produced in the leaves and stems increased with time up to 90 DAP and thereafter decreased. In the tubers, dry matters increased with time up to126 DAP. More dry matter was partitioned to the tubers than to the leaves and stems at all stages of growth. At the end of the growing season, $81 \%$ of the total dry matter produced has been partitioned to the tubers. In the accession Tukwak, the dry matter accumulated in the leaves and stems increased with time up to 90 DAP and thereafter decreased. The dry matter partitioned to the tubers increased with time up to 126 DAP. The proportion of dry matter in the leaves and stems was higher than in the tubers at the early stages of growth. At the latter stages, however, more dry matter $(81.8 \%)$ was partitioned to the tubers than to the leaves $(3.9 \%)$ or the stems $(14.3$ $\%$ ) (Table 2). The pattern of dry matter production and distribution in the accession Langtang shows that dry matter in the leaves and stems increased with time up to $90 \mathrm{DAP}$ and thereafter decreased. The dry matter accumulated in the tubers, however, increased with time up to 126 DAP. The proportion of dry matter in the tubers was higher at the latter than at the early stages of growth.

\section{Harvest index}

Table 3 shows the harvest index of some Hausa potato accessions at different stages of growth at Kuru, Nigeria. Generally, harvest index increased with time up to 126 DAP in all but accession Mujir. The highest harvest index at 45 DAP was observed in the accession Manchok $2(0.64)$ while the lowest was observed in the accession Langtang (0.20). At 90 DAP, the harvest index was statistically similar in all the accessions. At 126 DAP, the highest harvest index was observed in the accession Bokkos $1(0.88)$ and this was followed by accessions Manchok 1(0.85) and Bikka-Baban (0.83). The lowest harvest index of 0.46 was observed in the accession Mujir.

Table 3 Harvest index in some Hausa potato accessions at 45, 90 and 126 days after planting (DAP) at Kuru in 2016

\begin{tabular}{llll}
\hline $\begin{array}{l}\text { Growth Stage ( Days After } \\
\text { Planting) }\end{array}$ & & & \\
\hline Accession & 45 & 90 & 126 \\
Manchok I & $0.23^{\text {de }}$ & $0.51^{\mathrm{a}}$ & $0.85^{\mathrm{ab}}$ \\
Manchok 2 & $0.64^{\mathrm{a}}$ & $0.6 \mathrm{I}^{\mathrm{a}}$ & $0.70^{\mathrm{ab}}$ \\
Bokkos I & $0.22^{\mathrm{de}}$ & $0.66^{\mathrm{a}}$ & $0.88^{\mathrm{a}}$ \\
Bokkos 2 & $0.38^{\mathrm{cd}}$ & $0.57^{\mathrm{a}}$ & $0.76^{\mathrm{ab}}$ \\
Bikka- Baban & $0.32^{\mathrm{cde}}$ & $0.55^{\mathrm{a}}$ & $0.83^{\mathrm{ab}}$ \\
Mujir & $0.37^{\mathrm{cd}}$ & $0.51^{\mathrm{a}}$ & $0.46^{\mathrm{c}}$ \\
NRCRI (White) & $0.56^{\mathrm{ab}}$ & $0.67^{\mathrm{a}}$ & $0.76^{\mathrm{ab}}$ \\
Tukwak & $0.43^{\mathrm{bc}}$ & $0.64^{\mathrm{a}}$ & $0.82^{\mathrm{ab}}$ \\
Langtang & $0.20^{\mathrm{e}}$ & $0.62^{\mathrm{a}}$ & $0.63^{\mathrm{bc}}$ \\
CV (\%) & 18.29 & 22.64 & 12 \\
\hline
\end{tabular}

Means followed by the same letter(s) within the same column are not significantly different at $5 \%$ level of probability (Duncan's new Multiple-Range Test)

\section{Total tuber yield}

The highest total tuber yield of $3.83 \mathrm{t} \mathrm{ha}^{-1}$ was observed in the accession NRCRI (White) while the lowest yield of $0.10 \mathrm{t} \mathrm{ha}^{-1}$ was observed in the accession Langtang, but this did not differ significantly from accessions Bokkos $1\left(1.21 \mathrm{t} \mathrm{ha}^{-1}\right)$, Bokkos $2(1.42$ $\left.\mathrm{t} \mathrm{ha}^{-1}\right)$, Manchok $1\left(1.05 \mathrm{t} \mathrm{ha}^{-1}\right)$, Manchok $2\left(1.42 \mathrm{t} \mathrm{ha}^{-1}\right)$ and BikkaBaban (0.92 $\left.\mathrm{t} \mathrm{ha}^{-1}\right)$ (Table 4).

Table 4 Total tuber yield $\left(t \mathrm{ha}^{-1}\right)$ in some Hausa potato accessions in Kuru 2016

\begin{tabular}{ll}
\hline Accession & Tuber yield $\left(\mathbf{t ~ h a}{ }^{-1}\right)$ \\
\hline Manchok I & $1.05^{\mathrm{bc}}$ \\
Manchok 2 & $1.42^{\mathrm{b}}$ \\
Bokkos I & $1.21^{\mathrm{b}}$ \\
Bokkos 2 & $1.42^{\mathrm{b}}$ \\
Bikka-Baban & $0.92^{\mathrm{bc}}$ \\
Mujir & $0.12^{\mathrm{c}}$ \\
NRCRI (White) & $3.83^{\mathrm{a}}$ \\
Tukwak & $0.92^{\mathrm{bc}}$ \\
Langtang & $0.10^{\mathrm{c}}$ \\
CV (\%) & 33.88
\end{tabular}

Means followed by the same letter(s) within the same column are not significantly different at $5 \%$ level of probability (Duncan's new Multiple-Range Test)

\section{Proximate composition}

Table 5 shows the results of proximate analysis in some Hausa potato accessions grown in Kuru, Nigeria in 2016. The highest moisture content of $76.7 \%$ was observed in the accession Mujir while the lowest $(68.8 \%)$ was observed in the accession Langtang. Protein content was highest in the accession Bikka-Baban $(4.06 \mathrm{~g} / 100 \mathrm{~g})$ while the lowest $(1.60 \mathrm{~g} / 100 \mathrm{~g})$ was observed in the accession Mujir. Fibre was observed to be highest in the accession Mujir $(4.40 \mathrm{~g} / 100 \mathrm{~g})$ but this did not differ significantly $(\mathrm{P}=0.05)$ from the other accessions. Fat was observed to be highest in the accession Bokkos $2(0.60 \mathrm{~g} / 100 \mathrm{~g})$ but this did not differ significantly from the accession Langtang with a fat content of $0.35 \mathrm{~g} / 100 \mathrm{~g}$. The Ash content was similar in all the accessions. The highest nitrogen free extract of $22.84 \mathrm{~g} / 100 \mathrm{~g}$ was observed in the accession Langtang, which was followed by accessions Bikka-Baban (20.57g/100g) and NRCRI (White) (19.67g/100g). The lowest NFE of $15.58 \mathrm{~g} / 100 \mathrm{~g}$ was observed in the accession Mujir. The calcium content was statistically similar in all the accessions. Phosphorus ranged from $0.023 \mathrm{~g} / 100 \mathrm{~g}$ in the accession Bokkos 1 to $0.032 \mathrm{~g} / 100 \mathrm{~g}$ in the accession Tukwak. The highest Vitamin $\mathrm{C}$ of $16.41 \mathrm{mg} / 100 \mathrm{~g}$ was observed in the accession NRCRI (White), which differed significantly $(\mathrm{p}=0.05)$ from the accession Bikka-Baban with a value of $5.68 \mathrm{~g} / 100 \mathrm{~g}$. The highest iron content of $1.66 \mathrm{~g} / 100 \mathrm{~g}$ was observed in the accession Manchok 2, and this differed significantly from the other accessions at $\mathrm{p}=0.05$. 
Table 5 Nutritional composition in some Hausa potato accessions grown in Kuru in 2016

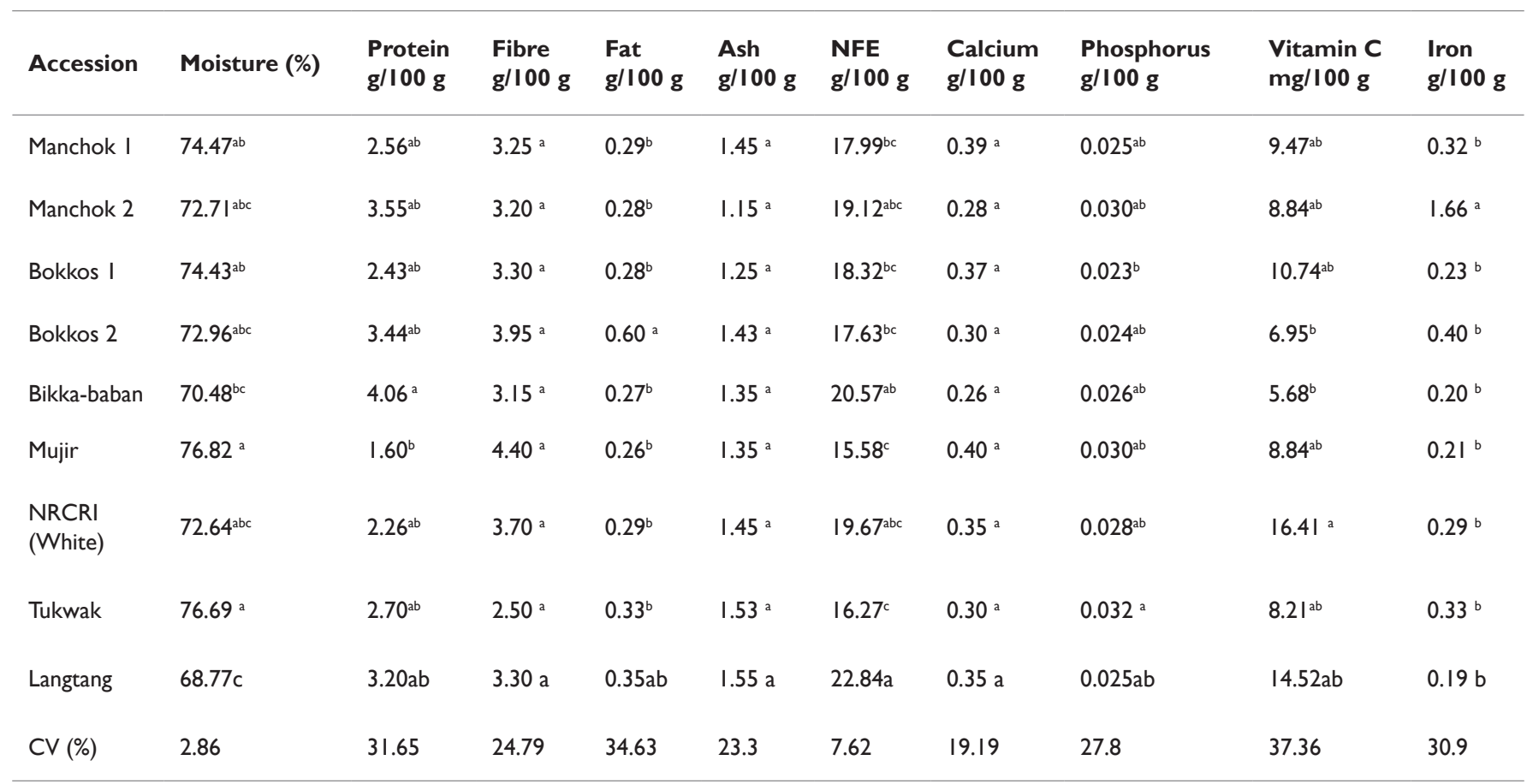

\section{Correlation matrix of proximate composition}

Table 6 shows the correlation matrix of the proximate composition in Hausa potato accessions grown in Kuru in 2016. Moisture content was negatively and significantly correlated with protein $\left(\mathrm{r}=-0.682^{*}\right)$ and Nitrogen Free Extract $\left(\mathrm{r}=-0.962^{* *}\right)$. Protein was positively correlated with NFE $\left(\mathrm{r}=0.553^{*}\right)$ but was negatively correlated with calcium $\left(\mathrm{r}=-0.855^{* *}\right)$. The ash content and iron were negatively and significantly correlated $\left(\mathrm{r}=-0.655^{*}\right)$.

Table 6 Correlation matrix of nutritional composition in some Hausa potato accessions grown in Kuru in 2016

\begin{tabular}{|c|c|c|c|c|c|c|c|c|c|c|}
\hline & Moisture & Protein & Fibre & Fat & Ash & NFE & Calcium & Phosphorus & Vitamin C & Iron \\
\hline Moisture & I & $-0.682 *$ & 0.093 & -0.137 & -0.101 & $-0.962^{* *}$ & 0.371 & 0.471 & -0.283 & -0.036 \\
\hline Protein & & I & -0.414 & 0.315 & -0.129 & $0.553 *$ & $-0.855^{* *}$ & -0.232 & -0.402 & 0.341 \\
\hline Fibre & & & I & 0.22 & -0.141 & -0.213 & 0.455 & -0.17 & 0.104 & -0.156 \\
\hline Fat & & & & 1 & 0.304 & -0.06 & -0.26 & -0.344 & -0.207 & -0.064 \\
\hline Ash & & & & & 1 & 0.13 & 0.174 & -0.012 & 0.305 & $-0.655^{*}$ \\
\hline NFE & & & & & & 1 & -0.248 & -0.421 & 0.451 & 0.009 \\
\hline Calcium & & & & & & & 1 & -0.184 & 0.463 & -0.422 \\
\hline Phosphorus & & & & & & & & I & -0.08 & 0.36 \\
\hline Vitamin C & & & & & & & & & I & -0.152 \\
\hline Iron & & & & & & & & & & I \\
\hline
\end{tabular}

* Significant at the $5 \%$ level of probability

** Significant at the I \% level of probability

NFE= Nitrogen Free Extract 


\section{Discussion}

The results of this study reveal that more dry matter was accumulated in the leaves than in the stems and the tubers at the early stages of growth; however, the reverse was the case at the latter stages of growth. More assimilates were partitioned to the roots than the leaves and stem in high-yielding accessions like Bokkos 1 and NRCRI (White). These accessions were also observed to have high root-top ratios. Harvest index increased with time up to 126 days after planting (126 DAP) in all accessions. Namo ${ }^{11}$ observed that harvest index increased with crop age in the sweet potato and that the peak period varied with genotype. The production of dry matter and its distribution to different parts of the plants is a major determinant of tuber yield in tuber and root crops. This activity is affected by the total dry matter produced, rate of translocation from the source (the leaves) to the roots or tubers (sink) and the balance between the source potential and the sink capacity. ${ }^{11}$ The need to evaluate the relationship between the source potential and the sink capacity in the Hausa potato is hereby recommended. This is because in spite of the high matter accumulated in the plant during the growing season, the total tuber yield in the crop is generally low as observed in this study. The low tuber yield observed in the present study is contrary to the findings of Enyiukwu et al. ${ }^{12} \&$ Reddy ${ }^{13}$ who reported average yields of between 5 and 15 tha $^{-1}$. The low tuber yield observed in this study could be due to poor acclimatization. Most of the accessions used in the study were introduced from other environments. The accession NRCRI (White) with the highest total tuber yield of 3.83 tha $^{-1}$ has been introduced to the Jos-Plateau environment many years ago. The study also observed differences in the germination period of the different accessions. There is, therefore, the need to induce the breaking of dormancy and synchronize the germination period of the different accessions in subsequent investigations.

Results of proximate analysis indicate that apart from fibre content, ash and calcium, all the other components varied with accession. The accession Bokkos 2 had the highest fibre and fat contents. The highest calcium and moisture contents were observed in the accession Mujir The highest protein, NFE, phosphorus, Vitamin $\mathrm{C}$ and iron contents were observed in the accessions Bikka-Baban, Langtang, Tukwak, NRCRI (White) and Manchok 2, respectively. The results suggest that selection for improvement in these mineral and nutrient components should be targeted at these accessions. The results of the multiple correlation analysis show that accession with a high moisture content to have low protein and nitrogen-free extract (NFE). Accessions with high protein were observed to have low calcium. Similarly, iron and ash content were negatively correlated. The results suggest that to improve tuber yield, protein and nitrogen -free extract in the Hausa potato, the moisture content, protein and fat contents of the targeted accessions should be decreased.

\section{Conclusion}

Results of this study indicate that dry matter accumulation and distribution varied with accession and time in all the Hausa potato accessions. The total dry matter produced and the proportion partitioned to the tubers affected the total tuber yield. The generally low tuber yield observed in this study could be due to slow rate of translocation of assimilates from the source (leaves) to the sink (tubers) or lack of balance between the source potential and sink capacity. It could have also been influenced by the fact that the accessions were newly introduced into the Jos-Plateau environment.
Proximate composition also varied with accession. The crude fibre, ash and calcium were, however, statistically similar in all the accessions. The study concludes that there is prospect for improving the productivity of the Hausa potato in the Jos-Plateau environment in order to address food shortages and Vitamin C deficiency among children and pregnant women.

\section{Acknowledgements}

The authors sincerely thank the potato sub-station of the National Root Crops Research Institute, Kuru, Nigeria for their technical support.

\section{Conflict of interest}

Author declares that there is no conflict of interest.

\section{References}

1. Nanema RK, Traore ER, Bationo P, et al. Morpho-agromical characterization of Solenostemon rotundifolius (Poir) J. K. Morton (Lamiaceae) germplasm from Burkina Faso. Int $J$ Biol Chem Sci. 2009;3:1100-1113.

2. Steentoft, M. Flowering Plants in West Africa. Cambridge: Cambridge University Press; 2009:268.

3. Akinpelu AO, Olojede AO, Amamgbo EF, et al. Response of Hausa potato to different NPK 15:15:15 Fertilizer Rates in NRCRI, Umudike, Abia State, Nigeria. Journal of Agriculture and Social Research, 2011;11(1):22-25.

4. Bradshaw JE. Plant Breeding: Past, Present and Future. India: Springer International Publishers; 2015:626.

5. Peter KV. Tuber and Root Crops. India: Horticulture Science Series; 2008:95.

6. AOAC. Official Methods of Analysis (1 $7^{\text {th }}$ Edition) Volume 1. Maryland USA: Association of Official Analytical Chemist Inc; 2000.

7. Koyuncu F, Cetinbas M, Ibrahim E. Nutritional constituents of wild-gram Black Mulberry (Morus nigra L.). Journal of Applied Botany and Food Quality. 2014;87:93-96.

8. Herch W, Kallel H, Bouchina S. Physico-chemical properties and antioxidant activity of Tunisian date palm (Phoenix dactylifera L.) oil as affected by different Extraction Methods. Food Science and Technology. 2014;34(3):464-470.

9. Nnamani, C.V., Oselebe, H.O. and Agbatutu, A. Assessment of nutritional values of three under-utilized indigenous leafy vegetables of Ebonyi State, Nisgeria. African Journal of Biotechnology. 2009;8:2321-2324.

10. Steel RGD, Torrie JH. Principles and Procedures of Statistics. New York: McGraw Hill Book Co. Inc; 1960:480.

11. Namo OAT. Screening for Source-Sink Potentials in Some Sweet Potato (Ipomoea batatas (L.) Lam.) Lines in Jos - Plateau, Nigeria. Published Ph.D. Thesis, University of Jos, Jos, Nigeria. Published by Lambert Academic Publishing, Omniscriptum GmbH Co. KG, Deutschland, Germany. 2005;240.

12. Enyiukwu DN, Awurum AN, Nwaneri JA. Potentials of Hausa Potato (Solenostemon rotundifolius (Poir) J. K. Morton) and management of its tuber rot in Nigeria. Greener Journal of Agronomy, Forestry and Horticulture. 2014;2(2):027-037.

13. Reddy PP. Plant Protection in Tropical Root and Tuber Crops. India: Springer International Publishers; 2015:336. 